\title{
Upaya Meningkatkan Hasil Belajar Servis Forehand Tenis Meja Menggunakan Media Modifikasi
}

\author{
${ }^{1}$ Rony M Rizal, ${ }^{2}$ Ruslan Rusmana, ${ }^{3}$ Erwin \\ ${ }^{1}$ Dosen Prodi. Magister Penjas STKIP Pasundan, Cimahi, Jawa Barat, Indonesia \\ ${ }^{2}$ Dosen Prodi. PJKR STKIP Pasundan, Cimahi, Jawa Barat, Indonesia \\ ${ }^{3}$ Mahasiswa Prodi. Magister Penjas STKIP Pasundan, Cimahi, Jawa Barat, Indonesia \\ denrony@gmail.com
}

\begin{abstract}
ABSTRAK
Tujuan dalam penelitian ini adalah untuk meningkatkan hasil belajar servis forehand siswa menggunakan media modifikasi. Metode penelitiannya adalah penelitian tindakan kelas (PTK). Subyek dalam penelitiannya adalah siswa kelas VII/A SMPN 2 Kota Cimahi. Penelitian ini dilakukan sebanyak empat kali pertemuan yang terdiri dari dua siklus, setiap siklus 2 kali pertemuan. Siklus pertama yang direalisasikan melalui tindakan sesuai rencana dan metode pembelajaran, hasilnya nilai rata-rata siswa dalam pembelajaran servis forehand adalah sebesar 68,06 atau 61,11\% siswa lulus, dan 38,89\% siswa belum lulus. Pada siklus ke dua yang direalisasikan melalui tindakan hasil refleksi dari siklus pertama, hasilnya nilai rata-rata siswa dalam pembelajaran servis forehand meningkat menjadi 77,78 atau $88,89 \%$ siswa lulus dan sisanya $11,11 \%$ siswa belum lulus. Berdasarkan hasil penelitian dapat disimpulkan bahwa pembelajaran tenis meja menggunakan media modifikasi dapat meningkatkan hasil belajar servis forehand siswa kelas VII/A SMPN 2 Kota Cimahi.
\end{abstract}

Kata Kunci: Media, Modifikasi, Servis Forehand, Tenis Meja

\section{ABSTRAC}

The purpose of this study is to improve student learning outcomes forehand services using media modification. The research method is classroom action research (CAR). The subjects in his research were students of class VII / A of SMPN 2 Cimahi City. This research was conducted four meetings consisting of two cycles, each cycle having 2 meetings. The first cycle is realized through action according to the plan and learning methods, the result is the average value of students in learning forehand services is 68.06 or $61.11 \%$ of students graduating, and 38.89\% of students have not graduated. In the second cycle which was realized through the results of reflections from the first cycle, the result was that the average value of students in learning forehand services increased to 77.78 or $88.89 \%$ of students graduated and the remaining $11.11 \%$ of students had not graduated. Based on the results of the study it can be concluded that learning table tennis using modified media can improve learning outcomes forehand service students of class VII / A of SMPN 2 Cimahi City.

Keyword: Media, Modification, Service Forehand, Table Tenis

Alamat Korespondensi: STKIP Pasundan

(C) 2020 STKIP Pasundan

Email: denrony@gmail.com

ISSN 2721-5660 (Cetak) 


\section{PENDAHULUAN}

Pendidikan Jasmani, Olahraga dan Kesehatan (PJOK) merupakan salah satu mata pelajaran yang wajib diberikan mulai dari tingkat pendidikan dasar sampai pada tingkat pendidikan menengah pertama (SMP) maupun tingkat menengah atas (SMA). Mata pelajaran ini diharapkan dapat memberikan kontribusi yang baik dalam upaya mengembangankan aspek fisik, mental, sosial dan emosional. J.S. Husdarta (2011:3) mengatakan bahwa: "Pendidikan jasmani dan kesehatan pada hakekatnya adalah proses pendidikan yang memanfaatkan aktivitas fisik dan kesehatan untuk menghasilkan perubahan holistik dalam kualitas individu, baik dalam hal fisik, mental, serta emosional".

Segala aktivitas yang diberikan pada pembelajaran pendidikan jasmani dapat melalui berbagai kegiatan seperti permainan, berbagai macam olahraga pilihan, pengembangan diri, akuatik, senam, dan pendidikan luar sekolah. Pada ruang lingkup pembelajaran mata pelajaran pendidikan jasmani terdapat materi ajar tentang permainan dan olahraga yang meliputi olahraga tradisional, permainan bola besar seperti bola basket, bola voli, sepak bola, dan permainan bola kecil seperti kasti, rounders, tenis meja, tenis lapang, serta keterampilan lokomotor, nonlokomotor, atletik, bela diri, dan aktivitas lainnya yang berhubungan dengan kebugaran jasmani, dan pola hidup yang sehat.

Seperti yang telah dikemukakan di atas bahwa salah satu bentuk kegiatan dalam pembelajaran pendidikan jasmani, olahraga dan kesehatan (PJOK) adalah permainan tenis meja. Permainan tenis meja ini lebih dikenal dengan sebutan "Pingpong" dan merupakan permainan yang cukup digemari dan mudah dipelajari serta enak ditonton. Putra mengatakan (2013:4) permainan tenis meja adalah olahraga semua umur dan bisa dianggap sebagai rekreasi maupun pemacu prestasi di sekolah. Selanjutnya Simpson (2008:5) mengatakan tenis meja dapat dianggap sebagai olahraga rekreasi, dan dapat juga dianggap sebagai olahraga yang harus ditanggulangi secara bersugguh-sungguh. Sedangkan Kosasih (2008:182) berpendapat bahwa tenis meja adalah suatu olahraga yang dimainkan di dalam gedung yang dimainkan oleh dua atau empat orang.

Namun bagi sebagian orang terutama di beberapa sekolah, permainan tenis meja ini jarang diberikan. Hal tersebut dikarenakan tidak tersedianya fasilitas yang menunjang terhadap pelaksanaan pembelajaran tenis meja, salah satunya adalah tidak tersedianya meja. Ini menyebabkan guru sedikit enggan untuk memberikan pelajaran permainan tenis meja. Di saming itu, permainan tenis meja juga dirasakan menjadi permainan yang tidak asing lagi bagi siswa SMP, sehingga terkadang permainan ini diasumsikan tidak perlu diberikan di tingkat SMP. Padahal sudah tercantum dalam kurikulum bahwa permainan tenis meja ini termasuk ke dalam kategori permainan bola kecil yang wajib diikuti oleh semua siswa pada kelas VII SMP. Dismaping itu, faktor cuaca yang sekarang ini tidak menentu seperti sering terjadinya hujan, membuat 
pembelajaran tenis meja ini kurang dilaksanakan secara optimal, sehingga tujuan dari pembelajaran tidak telaksana atau tidak tercapai secara optimal.

Seperti yang terdapat pada permainan bola kecil lainnya, permainan tenis meja juga terdapat gerakan-gerakan teknik dasar, salah satunya adalah servis forehand. Gerakan servis pada permainan tenis meja adalah merupakan salah satu gerakan teknik dasar yang harus dan wajib dikuasai oleh setiap orang yang sedang belajar tenis meja, karena servis ini merupakan suatu upaya dalam menyajikan bola pertama untuk memulai suatu permainan. Teknik dasar servis forehand dalam permainan tenis merupakan salah satu teknik dasar yang sangat penting, karena jika melakukannya dengan baik dan benar, lebih memungkinkan untuk menambah poin bagi yang melakukannya. Indra (2013:5) mengatakan "servis adalah memukul bola untuk menyajikan bola pertama. Service adalah teknik memukul untuk menyajikan bola pertama kedalam permainan, dengan cara memantulakan terlebih dahulu bola tersebut, ke meja server, kemudian harus melawati atas net dan akhirnya memantul di meja lawan".

Inovasi dan terobosan baru pada saat pelaksanaan proses belajar mengajar dengan menggunakan berbagai media dan metode yang baru harus terus dicoba guna meningkatnya kualitas pembelajaran, sehingga dapat memudahkan siswa dalam proses belajarnya. Suyanto (2008:40) mengatakan pada prinsipnya media pembelajaran berguna untuk memudahkan siswa belajar memahami sesuatu yang mungkin sulit atau menyederhanakan sesuatu yang kompleks. Terobosan dan inovasi baru akan penulis coba dengan mengubah pemikiran yang tadinya selalu mengandalkan alat-alat, peraturan dan prasarana yang standar atau yang sebenarnya, menjadi memanfaatkan peralatan, peraturan dan bentuk permainan yang sederhana, dapat dimodifikasi, sehingga dapat diterapkan dalam proses pembelajarannya. Modifikasi secara umum adalah mengubah atau menyesuaikan. Bahagia (2010:13), mengemukakan bahwa: "Modifikasi dapat diartikan sebagai upaya melakukan perubahan dengan penyesuaian-penyesuaianbaik dalamsegi fisik material (fasilitas dan perlengkapan) maupun dalam tujuan dan cara (metoda, gaya, pendekatan,aturan serta penilaian)". Dengan begitu proses pembelajaran pendidikan jasmani pada permainan tenis meja dapat dilakukan oleh seluruh siswa sesuai dengan kemampuan dan karakteristik perkembangan dan pertumbuhannya.

Pada penelitian ini penulis mencoba memberikan materi pembelajaran tenis meja khususnya pada teknik dasar servis forehand dengan menggunakan media meja sekolah dan media kardus, sehingga diharapkan pembelajaran tenis meja dapat dilakukan sebagaimana mestinya dan tuntutan kurikulum dapat terlaksanakan. Pembelajaran menggunakan media modifikasi merupakan salah satu bentuk pembelejaran yang berpusat pada siswa dan dapat merangsang gerak dasar, pemikiran, dan sikap siswa yang seluas-luasnya, sehingga akan dapat memungkinkan kemampuan motorik, kognitif, dan afektif siswa dapat berkembang dengan cepat dan tepat. 


\section{METODE}

Metode penelitian yang digunakan dalam penelitian ini adalah metode penelitian tindakan kelas. Desain penelitian tindakan yang digunakan adalah model dari kemmis dan Mc. Taggart, yang berupa satu siklus atau putaran kegiatan yang meliputi tahap-tahap rancangan pada setiap putarannya, yaitu diantaranya: (1) Perencanaan/Planning, (2) Tindakan/Acting, (3) Pengamatan/Observing, (4) Refleksi/Reflecting, dan akan diadakan revisi perencanaan pada siklus ulang jika masih diperlukan. Keempat langkah/tahapan tersebut dapat digambarkan sebagai berikut :

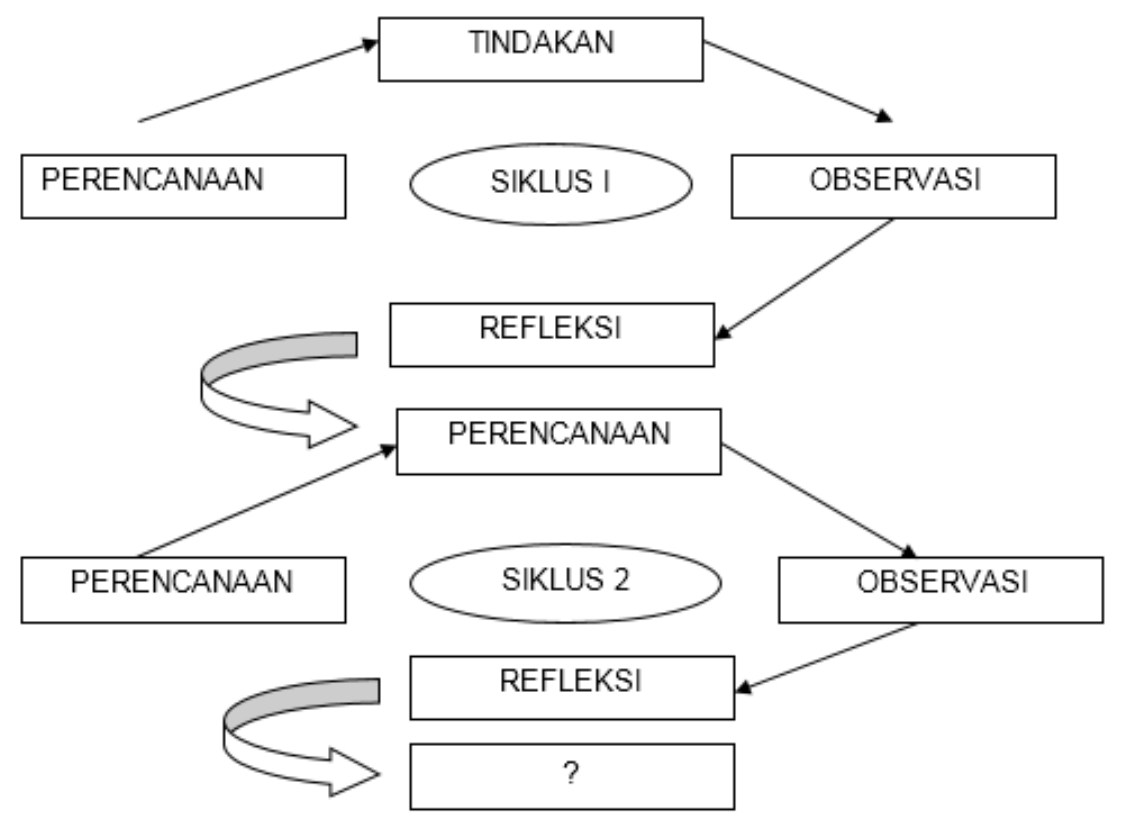

Gambar 1. Desain Penelitian Tindakan Model Kemmis dan Mc Taggart Sumber: Arikunto (2010:97)

Sumber data dari penelitian ini adalah siswa kelas VII/A SMPN 2 Kota Cimahi yang berjumlah 36 orang (putra 16 orang dan putri 20 orang). Instrumen yang digunakan dalam penelitian ini adalah tes hasil belajar servis forehand tenis meja. Kriteria keberhasilan tindakan dalam penelitian ini adalah 80\% dari jumlah keseluruhan siswa sudah memenuhi KKM (Nilai 70).

Teknik analisis data yang peneliti gunakan adalah dengan cara mengumpulkan data yang didapat dari sumber penelitian. Setelah data terkumpul, maka selanjutnya data tersebut dianalisis berdasarkan dari hasil observasi yang telah dilakukan. Data tersebut kemudian dituangkan dalam bentuk tabel dan diagram untuk selanjutnya dideskripsikan dengan membandingkan antara hasil pencapaian yang didapat dengan indikator keberhasilan yang telah ditentukan. 


\section{HASIL DAN PEMBAHASAN}

\section{Deskripsi Data Awal/Pra Siklus}

Sebelum melaksanakan proses penelitian tindakan, terlebih dahulu peneliti melakukan kajian atau observasi awal terhadap hasil belajar servis forehand tenis meja pada siswa kelas VII/A SMPN 2 Kota Cimahi. Adapun deskripsi data yang diambil adalah hasil belajar servis forehand tenis meja yang disajikan dalam bentuk tabel dan diagram sebagai berikut :

Tabel 1.

Hasil Tes Awal Hasil Belajar Servis Forehand Tenis Meja

\begin{tabular}{cccccc}
\hline No & Rentang Skor & Nilai & Frekuensi & Persentase & Kategori \\
\hline $\mathbf{1}$ & $3-4$ & 50 & 10 & $27,8 \%$ & Sangat Kurang \\
\hline $\mathbf{2}$ & $5-6$ & 60 & 13 & $36,1 \%$ & Kurang \\
\hline $\mathbf{3}$ & $7-8$ & 70 & 8 & $22,2 \%$ & Cukup \\
\hline $\mathbf{4}$ & $9-10$ & 80 & 3 & $8,3 \%$ & Baik \\
\hline $\mathbf{5}$ & $11-12$ & 90 & 2 & $5,6 \%$ & Sangat Baik \\
\hline & Jumlah & & $\mathbf{3 6}$ & $\mathbf{1 0 0 \%}$ & \\
\hline
\end{tabular}

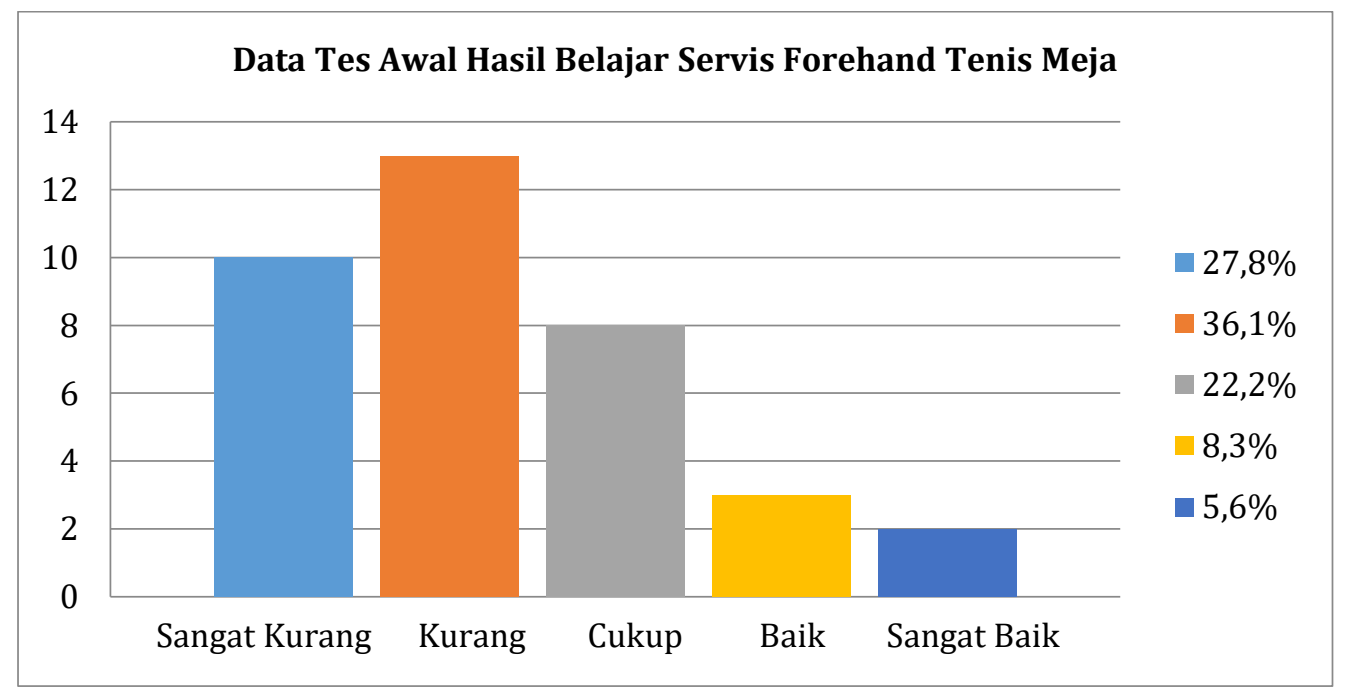

Gambar 2. Diagram Data Tes Awal Hasil Belajar Servis Forehand

Berdasarkan data tersebut di atas dapat dilihat bahwa sebelum diberikan tindakan mayoritas siswa belum menunjukan hasil belajar yang cukup baik atau belum memenuhi Kriteria Ketuntasan Minimal (KKM). Hal tersebut dapat dibuktikan dengan adanya 23 orang siswa yang belum memenuhi target dari KKM atau 63,9\% siswa yang belum lulus, dan berdasarkan hasil perhitungan nilai rata-ratanya adalah sebesar 62,78. Maka dari itu peneliti menyusun sebuah tindakan pembelajaran dengan menggunakan media modifikasi untuk meningkatkan hasil belajar servis forehand siswa kelas VII/A di SMPN 2 Kota Cimahi. 


\section{Siklus 1}

Pada dasarnya pembelajaran servis forehand dengan menggunakan media modifikasi berupa meja sekolah dan kardus sudah cukup memberikan semangat kepada siswa dalam melaksanakan proses belajarnya, sehingga siswa lebih antusias dalam mengikuti pembelajaran. Hal tersebut dapat diamati melalui hasil tes dan hasil observasi dari para kolaborator. Bagian ini merupakan paparan tentang data hasil tes belajar servis forehand siklus I, yang nantinya akan menjadi dasar perencanaan untuk penetapan revisi tindakan yang akan dilakukan pada siklus II. Tes Hasil belajar servis forehand tenis meja yang diperoleh siswa pada pembelajaran siklus 1 ini, akan disajikan dalam bentuk tabel dan diagram batang sebagai berikut :

Tabel 2.

Hasil Belajar Servis Forehand Tenis Meja Siklus I

\begin{tabular}{cccccc}
\hline No & Rentang Skor & Nilai & Frekuensi & Persentase & Kategori \\
\hline $\mathbf{1}$ & $3-4$ & 50 & 5 & $13,9 \%$ & Sangat Kurang \\
\hline $\mathbf{2}$ & $5-6$ & 60 & 9 & $25 \%$ & Kurang \\
\hline $\mathbf{3}$ & $7-8$ & 70 & 13 & $36,1 \%$ & Cukup \\
\hline $\mathbf{4}$ & $9-10$ & 80 & 6 & $16,7 \%$ & Baik \\
\hline $\mathbf{5}$ & $11-12$ & 90 & 3 & $8,3 \%$ & Sangat Baik \\
\hline & Jumlah & & $\mathbf{3 6}$ & $\mathbf{1 0 0 \%}$ & \\
\hline
\end{tabular}

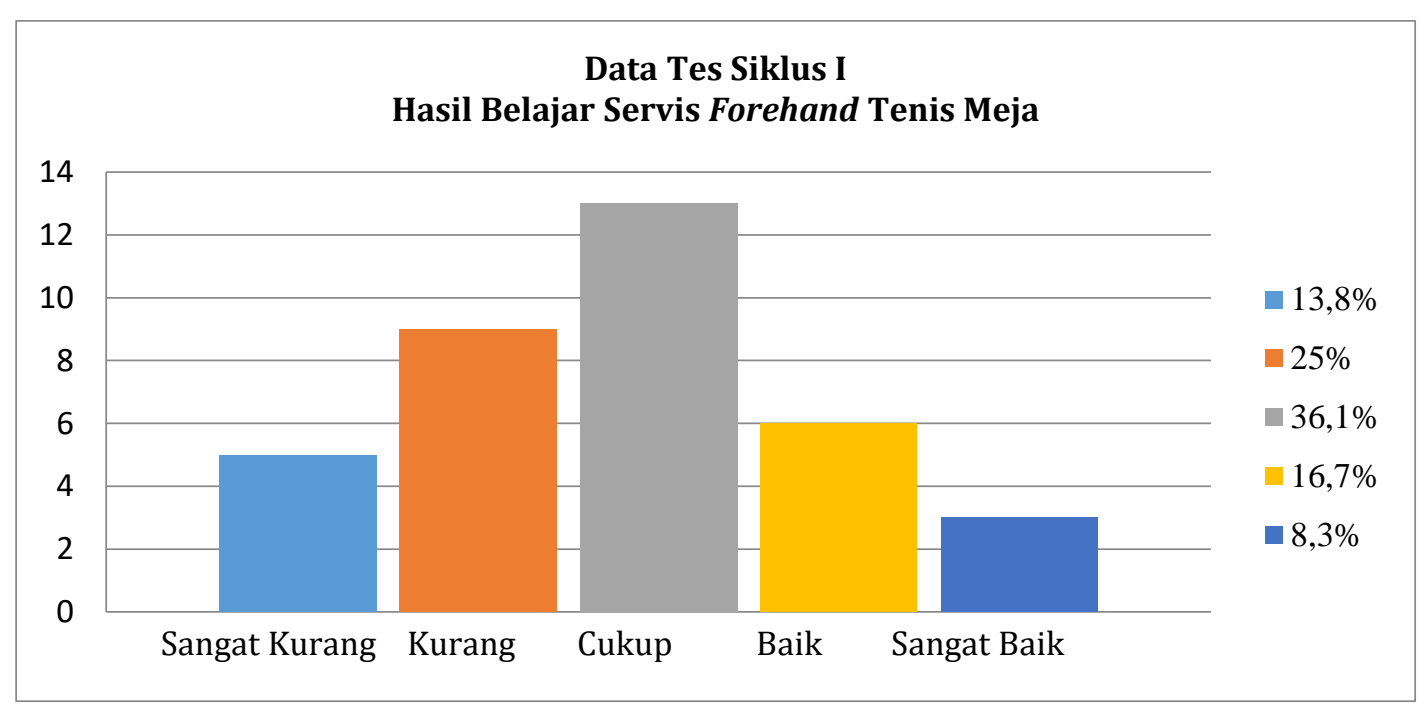

Gambar 3. Diagram Data Hasil Belajar Servis Forehand Siklus I

Berdasarkan data tersebut di atas dapat dilihat bahwa setelah diberikannya tindakan pada siklus I, siswa sudah dapat menunjukan hasil belajar yang cukup baik. Hal tersebut terlihat dengan adanya peningkatan siswa yang sudah lulus atau sudah memenuhi KKM yaitu sebanyak 22 orang atau 61,11\% dari jumlah keseluruhan siswa yaitu sebanyak 36 orang, dan berdasarkan perhitungan didapat nilai rata-ratanya adalah sebesar 68,06. 
Hasil tersebut dirasakan masih kurang memuaskan bagi peneliti, karena belum memenuhi target atau kriteria keberhasilan yang sudah peneliti tetapkan sebelumnya, yaitu 80\% dari jumlah keseluruhan siswa harus lulus atau sudah memenuhi KKM. Maka dari itu, peneliti perlu menyusun kembali sebuah tindakan pada siklus berikutnya agar target atau kriteria keberhasilan pada penelitian ini dapat tercapai.

\section{Siklus 2}

Berdasarkan hasil dari pengamatan pada siklus II ini mengenai jalannya proses belajar mangajar, terlihat bahwa guru telah melaksanakan berbagai ketentuan dalam pembelajaraanya dengan baik. Guru sudah dapat menjelaskan akan manfaat dari melakukan gerakan yang telah dilakukan, sehingga para siswa lebih mengerti dan memahami fungsi dari gerakan yang telah diajarkan kepadanya. Di samping itu, peneliti juga sudah dapat mengkondisikan kelas dengan baik. Kelas menjadi lebih tertib dan teratur, serta terlihat bersifat aktif, hal tersebut terlihat dengan keterlibatan dan keseriusan siswa dalam melakukan setiap instruksi yang diberikan oleh guru. Bentuk-bentuk permainan yang diberikan sudah mengarah kepada gerakan servis forehand tenis meja, lebih variatif dan kompetitif. Hal tersebut membuat siswa merasa lebih termotivasi lagi dalam menjalankan proses pembelajarannya.

Selanjutnya pada bagian ini peneliti akan memaparkan data tentang hasil tes belajar servis forehand siklus II. Tes tersebut akan disajikan dalam bentuk tabel dan diagram sebagai berikut :

Tabel 3.

Hasil Belajar Servis Forehand Tenis Meja Siklus II

\begin{tabular}{cccccc}
\hline No & Rentang Skor & Nilai & Frekuensi & Persentase & Kategori \\
\hline $\mathbf{1}$ & $3-4$ & 50 & 0 & $0,0 \%$ & Sangat Kurang \\
\hline $\mathbf{2}$ & $5-6$ & 60 & 4 & $11,1 \%$ & Kurang \\
\hline $\mathbf{3}$ & $7-8$ & 70 & 9 & $25 \%$ & Cukup \\
\hline $\mathbf{4}$ & $9-10$ & 80 & 16 & $44,4 \%$ & Baik \\
\hline $\mathbf{5}$ & $11-12$ & 90 & 7 & $19,4 \%$ & Sangat Baik \\
\hline & Jumlah & & $\mathbf{3 6}$ & $\mathbf{1 0 0 \%}$ & \\
& & & & &
\end{tabular}




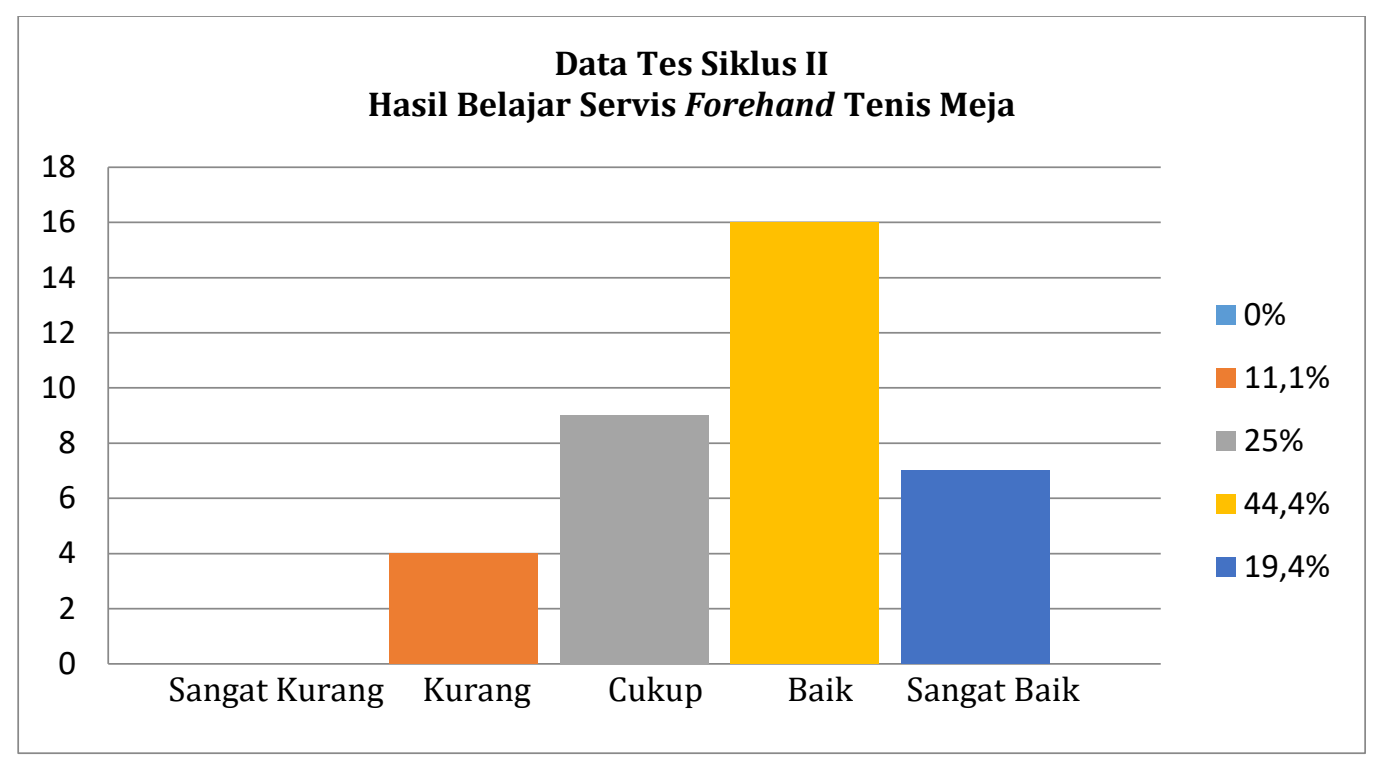

Gambar 4. Diagram Data Hasil Belajar Servis Forehand Siklus II

Berdasarkan data tersebut di atas dapat dilihat bahwa setelah diberikannya tindakan pada siklus II, hasil belajar servis forehand tenis meja siswa meningkat. Hal tersebut terlihat dengan adanya peningkatan siswa yang sudah lulus atau sudah memenuhi KKM yaitu sebanyak 32 orang atau 88,89\% dari jumlah keseluruhan siswa yaitu sebanyak 36 orang, dan berdasarkan hasil perhitungan diperoleh nilai rata-ratanya adalah sebesar 77,78. Hasil tersebut menunjukan bahwa target atau kriteria keberhasilan yang sudah peneliti tetapkan sebelumnya sudah tercapai, yaitu $80 \%$ dari jumlah keseluruhan siswa harus lulus atau sudah memenuhi KKM.

Setelah selesai melakukan penelitian pada siklus I dan siklus II, maka peneliti bersama dengan kolaborator menganalisis data dari hasil pengamatan selama proses penelitian berlangsung. Data tersebut berupa angka-angka kuantitatif yang dibandingkan antara siklus I dan dan siklus II. Untuk lebih jelasnya mengenai perbandingan pencapaian hasil belajar servis forehand tenis meja antara siklus I dan siklus II dapat dilihat pada tabel dan diagram batang berikut ini:

Tabel 4.

Hasil Belajar Servis Forehand Pra Siklus, Siklus I dan Siklus II

\begin{tabular}{ccccccccc}
\hline \multirow{2}{*}{ No } & \multirow{2}{*}{ Nilai } & \multicolumn{2}{c}{ Pra Siklus } & \multicolumn{2}{c}{ Siklus I } & \multicolumn{2}{c}{ Siklus II } & \multirow{2}{*}{ Keterangan } \\
\cline { 3 - 7 } & & $\mathbf{F}$ & $\mathbf{\%}$ & $\mathbf{F}$ & $\mathbf{\%}$ & $\mathbf{F}$ & $\mathbf{\%}$ & \\
\hline $\mathbf{1}$ & $\geq 70$ & 13 & 36,11 & 22 & 61,11 & 32 & 88,89 & Lulus \\
\hline $\mathbf{2}$ & $<70$ & 23 & 63,89 & 14 & 38,89 & 4 & 11,11 & Belum Lulus \\
\hline & Jumlah & $\mathbf{3 6}$ & $\mathbf{1 0 0}$ & $\mathbf{3 6}$ & $\mathbf{1 0 0}$ & $\mathbf{3 6}$ & $\mathbf{1 0 0}$ & \\
\hline
\end{tabular}




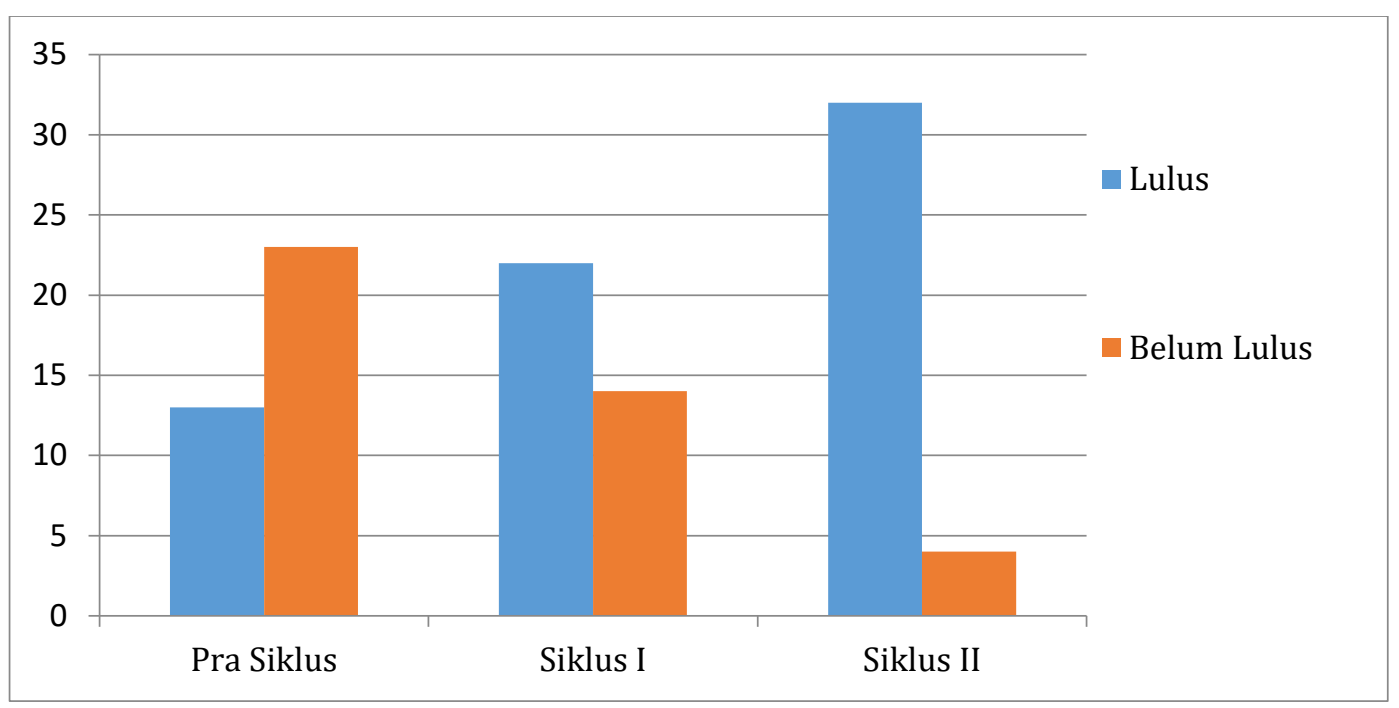

Gambar 5. Grafik Perbandingan Hasil Belajar Servis Forehand

Berdasarkan dari tabel di atas dapat disimpulkan bahwa pada data awal siswa yang sudah lulus ada sebanyak 13 orang atau 36,11\% dari jumlah keseluruhan siswa, dan yang belum lulus ada 23 orang atau $63,89 \%$ dari jumlah keseluruhan siswa. Kemudian pada siklus I siswa yang lulus atau sudah memenuhi KKM ada sebanyak 22 orang atau $61,11 \%$ dari jumlah keseluruhan siswa, dan yang belum lulus ada sebanyak 14 orang atau 38,89\% dari jumlah keseluruhan siswa. Sedangkan pada siklus II dapat terlihat bahwa adanya peningkatan mengenai kelulusan hasil belajar passing bawah, bahwa siswa yang sudah lulus ada sebanyak 32 orang atau 88,89\% dari jumlah keseluruhan siswa, dan yang belum lulus hanya ada 4 orang siswa atau $11,11 \%$ dari jumlah keseluruhan siswa. Dengan demikian dapat disimpulkan bahwa hasil belajar servis forehand tenis meja terdapat peningkatan pada setiap siklusnya.

\section{KESIMPULAN}

Berdasarkan hasil penelitian yang telah dipaparkan sebelumnya, maka peneliti menyimpulkan bahwa penggunaan media modifikasi dalam pembelajaran tenis meja dapat meningkatkan hasil belajar servis forehand siswa kelas VII/A SMPN 2 Kota Cimahi. Penelitian ini memberikan gambaran yang jelas bahwa dengan menggunakan media modifikasi hasil belajar servis forehand tenis meja dapat meningkat. Hasil penelitian ini juga dapat digunakan sebagai suatu masukan bagi guru pendidikan jasmani khususnya untuk menggunakan media pembelajaran yang dimodifikasi pada pembelajaran pendidikan jasmani. Jadi tidak harus menggunakan peralatan yang sebenarnya. 


\section{DAFTAR PUSTAKA}

Arikunto. (2010). Prosedur Penelitian Suatu Pendekatan Praktik. Jakarta : Rineka Cipta.

Bahagia. (2010). Media dan Pembelajaran Penjas. Bandung: FPOK UPI.

Husdarta, S. J. (2011). Manajemen Pendidikan Jasmani. Bandung: Alfabeta.

Putra, E. S. (2013). Upaya Meninngkatkan Hasil Belajar Servis Backhand dalam Permainan Tenis Meja Melalui Media Dinding. Palembang: Universitas Bina Dharma.

Simpson. (2008). Teknik Bermain Pingpong. Bandung: Pioner Jaya.

Kosasih. (2008). Pendidikan Jasmani Untuk SMP. Senajaya: Gelora Aksara Pratama.

Indra. (2013). Meningkatkan Kemampuan Pukulan Backhand dalam Permainan Tenis Meja dengan Menggunakan Metode Pelatihan Memantulkan Bola Ke Dinding Pada Siswa Putra Kelas VIII SMP Negeri 1 Muaro Jambi. Jambi: FKIP Universitas Jambi.

Suyato, S. (2008). Strategi Pendidikan Anak. Yogyakarta: Hikayat Publising. 